\title{
Analysis of Land Use and Land Cover Changes, and Their Ecological Implications in Wuhan, China
}

\author{
Victor Tamba Simbay Kabba (Corresponding author) \\ Department of Land Resources Management, Faculty of Economy and Management \\ China University of Geosciences (Wuhan), 388 Lumo Lu, International Education College \\ International Cooperation Office, East campus \\ Hongshan District, Wuchang, Wuhan 430074, Hubei, China \\ Tel: 86-158-2748-0592 E-mail:Victor_kabba@yahoo.co.uk \\ $\&$ \\ Institute of Geography and Development Studies, School of Environmental Sciences \\ Njala University, Private Mail Bag, Freetown, Republic of Sierra Leone \\ E-mail: tamba02kay@yahoo.com \\ Jiangfeng Li \\ Department of Land Resources Management, Faculty of Earth Resources \\ China University of Geosciences (Wuhan), Room 610, Wen Hua Building, West campus, \\ Wuhan 430074, Hubei, China \\ Tel: 86-139-7101-2496 E-mail: jfli@cug.edu.cn
}

Received: December 31, 2010 Accepted: January 21, 2011 doi:10.5539/jgg.v3n1p104

\begin{abstract}
This study investigated land use changes, and their ecological effects in Wuhan (1987-2005). Remote Sensing techniques extracted land use data, whilst the spatial analyst software, Fragstats quantified ecological metrics at both landscape and class levels. The results showed increased urban and agricultural land uses (1987-2005); with urban land increasing more than 250 percent. This was largely attributed to: i) state favors accorded to it as the economic, industrial, scientific and cultural hub of central China; and ii) socioeconomic reforms. This is also shown by the positive correlation between urban growth and socioeconomic variables in the order GDP $>$ per capita GDP > per capita annual net urban income. Ecological metrics at landscape level (example, number of patches, Shannon and Simpson's diversity Indices) showed that fragmentation strengthened (1987-1994), but weakened (1994-2005). Socioeconomic factors and ecological metrics indeed explained land use changes and their effects in Wuhan.
\end{abstract}

Keywords: Land use and land cover changes, Ecological metrics, Remote sensing, Ecological implications, Fragstats, Fragmentation, Socioeconomic variables

\section{Introduction}

Land use in China accelerated after the open-door policy in 1978. The social and economic reforms that followed have resulted in increased economic growth and urbanization throughout the country. Urbanization rose from 17 percent in 1978 to 41 percent in 2006 (State Statistical Bureau, various years). One urban area that has been singled out for this research is Wuhan. Like most major cities in China, its population and economy has grown over the years. Unfortunately, the natural landscape, especially its arable land has been reduced significantly through various land use land cover changes. It is generally important for accurate and timely land use land cover change data to be available to policy makers, including governments at local, regional and national scales, and researchers, on the scale of such changes on the ecological system. Previous research (Chibamba, 2009; Cheng and Masser, 2002; Cheng, 2003; Yingui, 2002) related land use land cover change to socioeconomic factors such as direct foreign investment, gross domestic product, and spatial policy. This 
research has taken a step further by using landscape ecological metrics to explain the effects of land use change on its natural landscape. It therefore attempts to address two main objectives: i) to analyze land use land cover changes in the study area between 1987 and 2005; ii) to analyze the relationship (if any) between urban expansion and socioeconomic variables; and iii) to analyze the ecological effects of such land use land cover changes on the natural landscape.

Following the Earth Summit in Rio de Janeiro in 1992, many studies have concentrated on environmental issues which have influenced the natural systems greatly (Benjaminsen, 2001; Glicken, 2000). Dramatic changes on the natural landscape brought concern to scientists as well as policy makers. These changes are the result of past (Burgi et al, 2002) and present socio-economic factors (Buchecker et al, 2003). This makes the integration of man's activities into landscape studies most relevant (Wu and Hobbs, 2002).

Land use/ land cover change is one of those major challenges that affect the natural landscape. It is one of the main driving forces of global environmental change, and central to the sustainable development debate (Lambin et al, 2000). The causes and consequences of land use change on the physical and social environment have been a gray area for research (Veldkamp and Verburg, 2004). These include its impact on water quality, land and air resources, ecosystem processes and function, and climate (Lambin et al,2000); biodiversity (Liu and Ashton,1998),soil degradation (Trimble and Crosson,2000) and the ability of natural systems to support life (Vitousek et al.1997).

A number of international research projects, example, The International Geosphere-Biosphere Project (1988) and The Land Use land Cover Change program (Messerli,1997) were initiated in a bid to construct an updated and accurate database concerning observed changes, their meaning, pace, magnitude and driving forces behind such changes (Mather,1999). Quantifying changes in the landscape is very important for an understanding of the spatial and structural variability in land use and their associated ecological effects (Turner, 2005). The method and scope used for such land use change study depends on the ecological process under study (Wiens, 1989; Allen and Hoekstra, 1992). Often times, an interdisciplinary approach, integrating the social and natural sciences have been argued (Lambin et al, 1999; Briassoulis, 1999) and in many research projects (e.g. Van der Veen and Otter, 2001). The use of regression equations and models has been extensive and valuable. For example, Wu et al (2006) used land maximization regression and Markov chain models to monitor and predict land use change; Sonis et al used matrix land-use analysis; Nagashima et al (2002) used discriminant analysis to understand the driving forces of land use change; and Yeh and $\mathrm{Li}$ (2002) used neural networks and cellular automata for land use planning.

Remote Sensing and Geographical Information Systems (GIS) (Jat et al, 2008; Wu et al, 2006; Li et al, 2005; Yuan et al, 2005) approaches have added a new dimension to the understanding of these changes, not least the urban landscape. Remote sensing techniques have been useful in the quantification of land use changes, especially from arable land to impermeable surfaces (Milesi et al, 2003). They monitor the spatio-temporal and dynamic changes in land use/land cover at regular intervals, using multi-temporal remote sensing satellite data such as Landsat TM images. These changes are of significance in the field of environmental change (Turner, 2003; Lambin et al, 2001). Geographical information system provides the platform on which data on such images are stored, processed and analyzed for decision making.

In recent years, landscape ecology introduced the use of landscape ecological indices or metrics to quantitatively assess landscape fragmentation, especially forest ecosystems. However, their use has in recent times become a trend in urban landscape change studies (Palmert, 2004; Leitao and Ahern, 2002; Sepp, 2006; Aranzabal et al, 2008; Cushman, 2008). Their quantification has helped in understanding the spatio-temporal dimensional changes of urban growth occurring on natural landscape (Sudhira et al, 2004). This has been shown in previous studies (Medley et al, 1995; McDonnell and Pickett, 1990; Costanza et al 1997; Matthews, 2006; Lacitignola et al, 2007; Wang and Zhang,; Kong and Nakagoshi, 2006; Guo,2001) to be more effective in explaining the interrelationship between and among land use land cover changes, the drivers of such changes, and effects of such changes on urban ecological landscape. It is this interrelationship that this research has tried to analyze and understand. We have therefore tested the effectiveness of remote sensing and GIS techniques, and Fragstats (version 3.3) (McGarigal and Marks, 1994) software in this research. Remote sensing and GIS techniques were used to obtain the biophysical and man-made information from three Landsat TM images. The spatial analyst software, Fragstats 3.3 which provides a very comprehensive set of spatial statistics and descriptive metrics of pattern at the patch, class, and landscape levels (Haines-Young \& Chopping, 1996), was then used to quantify landscape metrics at both landscape and class levels. 


\section{Materials and methods}

\subsection{Site description}

Wuhan is the provincial seat of Hubei Province, and the largest city in central China (Fig.1). Found at the confluence of the Yangtze and Hanshui Rivers, east of Jianghan plains, it is a conglomeration of three towns: Wuchang, Hanyang and Hankou, all three separated by the rivers. With an area extent of $8,467.11 \mathrm{~km}^{2}(3,269.2$ sq mi), its population has risen from 6.24 million in 1987 to 9.1 million in 2007(WSYB, 2008). The economic and social reforms in late 1970s have made it emerged as the biggest industrial and commercial city in middle China, with a complete industrial system in respect of iron/steel, automobile, optical electronics, chemical making, metallurgy, textile, ship-building, manufacturing and pharmaceuticals. This is reflected in the growth of its GDP from 12.46 billion in 1987 to 223.8 billion in 2005 . These growths have caused tremendous changes in its land use and land cover between 1987 and 2005 (the period under investigation), with inevitable ecological consequences. The main thrust of this paper is therefore to analyze the ecological effects of its land use land cover dynamics, giving the socioeconomic and population changes that have taken place between 1987 and 2005.

\subsection{Methods}

\subsubsection{Remote sensing}

\subsubsection{Pre-processing image}

The standard image processing techniques of extraction, layer stacking, geometric correction/ georeferencing and change detection were performed on the three Landsat TM images (Table 1) obtained on different dates. They served as the primary data for this study. The rationale for using these dates stem from the fact that it was within these periods that major decisions such as migration policy (from rural to urban), Wuhan's special economic preference, and policy on protection of agricultural land, were made. Obtaining near anniversary images would have been preferable but this proved impossible for us. The 1987 and 2005 images were geometrically corrected to a common Universal Transverse Mercator coordinate system, Datum WGS 1984; Zone 49, based on a 1:50,000 topographic map scale, the 1994 image used as the MASTER image. The resultant Root Mean-Squared (RMS) of the georeferenced process, are presented in Table 1. These were good as rectification of an image should have a root mean square error of $\leq 0.5$ (Jensen, 2007). Resampling, using the nearest neighbor algorithm to keep the original brightness values of the pixels unchanged was then done on the images.

\subsubsection{Image classification}

The satellite images were classified into land use classes. Anderson et al (1976) and Chinese Academy of Science's land use/ land cover Classification Systems were modified to classify the images into four land use classes: built-up (impervious layers such as residential and commercial services, office blocks, educational centres, hospitals, manufacturing industries, motor roads, rails etc); water (Rivers, lakes, ponds, lagoons, dams, marsh wetlands ); agriculture (all cultivated areas such as farmlands, crop fields including vegetable gardens, plantations, fallow plots) and forest(protective forests, timber forest, economic forest, firewood forest and forests of special use). Using ERDAS IMAGINE 9.2 software, the supervised classification system, using maximum likelihood algorithm was performed on the images. Goggle earth, and data collected during field trips (training sites/ground control points using GPS) served as reference data. The accuracy of the images was checked and the overall accuracy and kappa indices (Table 1) were deemed satisfactory for land use change analysis.

\subsubsection{Metrics selection}

The need for a quantitative description of ecological heterogeneity has long been the objective of ecology (Pielou, 1977).The introduction of landscape metrics has helped in explaining the variability (over time) of landscape structure and composition. Selecting metrics for a given study involves a number of considerations. Firstly, because a few primary measurements can be made from patches (patch type, area, edge, and neighbour type), most metrics correlate among themselves (McGarigal et al, 2002). Secondly, the objectives of study, spatial characteristics of the system and ecological processes under investigation determine which metrics to use (Gustafson, 1998). Taking these into consideration, seven (7) landscape level metrics and five (5) class level metrics were chosen to quantify and examine spatio-temporal changes in Wuhan's landscape composition and configuration between 1987 and 2005. Complete descriptions of these metrics and equations for their calculation are provided in McGarigal et al (2002) and McGarigal and Marks (1995).

\subsubsection{Calculating metrics in Fragstats}

For Fragstats to compute landscape metrics, recode and modelling processes were first carried out on the images in ERDAS Imagine 9.2 software. The resulting images were stored as signed- 8 bit files. The raster version of 
Fragstats 3.3 was used in this study. The Fragstats itself was embedded into ArcGIS 9.2 software for it to be enabled. The following metrics were quantified:

2.2.3.1 Landscape level metrics

(a) Number of patches $(N P)$ : Is the number of patches of the corresponding patch type (class). Higher NumP indicates greater fragmentation.

$$
\mathrm{NP}=\mathrm{n}_{\mathrm{i}}
$$

Where $\mathrm{n}_{\mathrm{i}}=$ number of patches in the landscape of patch type (class) $\mathrm{i}$.

(b) Patch density $(P D)$ : equals the number of patches of the corresponding patch type divided by total landscape area $\left(\mathrm{m}^{2}\right)$.

$$
P D=\frac{n_{i}}{A}(10,000)(100)
$$

Where $n_{i}=$ number of patches in the landscape of patch type (class) $i$.

$\mathrm{A}=$ total landscape area $\left(\mathrm{m}^{2}\right)$.

(c) Largest Patch Index (LPI): the area of the largest patch in each class (in hectares).

$$
L P I=\frac{\max _{j=1}^{n}\left(a_{i j}\right)}{A}(100)
$$

Where $\mathrm{a}_{\mathrm{ij}}=$ area $\left(\mathrm{m}^{2}\right)$ of patch $\mathrm{ij} . \mathrm{A}=$ total landscape area $\left(\mathrm{m}^{2}\right)$.

(d) Shannon's Diversity index (SHDI): equals minus the sum, across all patch types, of the proportional abundance of each patch type multiplied by that proportion

$$
S H D I=-\sum_{i=1}^{m}\left(P_{i}^{e} \ln P_{i}\right)
$$

Where $\mathrm{P}_{\mathrm{i}}=$ proportion of the landscape occupied by patch type (class) $\mathrm{i}$.

(e) Simpson's diversity Index equals 1 minus the sum, across all patch types, of the proportional abundance of each patch type squared. Note, $P_{i}$ is based on total landscape area $(A)$ excluding any internal background present.

$$
S I D I=1-\sum_{i=1}^{m} P_{i}^{2}
$$

Where $\mathrm{P}_{\mathrm{i}}=$ proportion of the landscape occupied by patch type (class) $\mathrm{i}$.

(f) Contagion index (CONT): equals minus the sum of the proportional abundance of each patch type multiplied by the proportion of adjacencies between cells of that patch type and another patch type, multiplied by the logarithm of the same quantity, summed over each unique adjacency type and each patch type; divided by 2 times the logarithm of the number of patch types; multiplied by 100 (to convert to a percentage).

$$
\text { CONTAG }=\left\{1+\frac{\left.\sum_{i=1}^{m} \sum_{k=1}^{m}\left[\left(P_{i}\right)\left(\frac{g_{i k}}{\sum_{k=1}^{m} g_{i k}}\right)\right] \cdot \ln \left(P_{i}\right)\left(\frac{g_{i k}}{\sum_{k=1}^{m} g_{i k}}\right)\right]}{2 \ln (m)}\right\} \times 100
$$

Where $\mathrm{P}_{\mathrm{i}}=$ proportion of the landscape occupied by patch type (class) $\mathrm{i}$.

$\mathrm{g}_{\mathrm{ik}}=$ number of adjacencies (joins) between pixels of patch types (classes) $\mathrm{i}$ and $\mathrm{k}$ based on the double-count method

$\mathrm{m}=$ number of patch types (classes) present in the landscape, including the landscape border if present.

(g) Fractal Dimension (mean)equals the sum of 2 times the logarithm of patch perimeter $(\mathrm{m})$ divided by the logarithm of patch area $(\mathrm{m} 2)$ for each patch in the landscape, divided by the number of patches. 


$$
F R A C=\frac{2 \ln \left(.25 p i_{j}\right)}{\ln a_{i j}}
$$

Where $\mathrm{p}_{\mathrm{ij}}=$ perimeter $(\mathrm{m})$ of patch $\mathrm{ij}$.

$\mathrm{a}_{\mathrm{ij}}=\operatorname{area}\left(\mathrm{m}^{2}\right)$ of patch $\mathrm{ij}$.

\subsubsection{Class level metrics}

(a) Number of patches $(N P)$ : Is the number of patches of the corresponding patch type (class). Higher NumP indicates greater fragmentation

$$
\mathrm{NP}=\mathrm{n}_{\mathrm{i}}
$$

Where $\mathrm{n}_{\mathrm{i}}=$ number of patches in the landscape of patch type (class) $\mathrm{i}$.

(b) Patch density $(P D)$ : equals the number of patches of the corresponding patch type divided by total landscape area $\left(\mathrm{m}^{2}\right)$

$$
P D=\frac{n_{i}}{A}(10,000)(100)
$$

Where $\mathrm{n}_{\mathrm{i}}=$ number of patches in the landscape of patch type (class) $\mathrm{i}$.

A $=$ total landscape area $\left(\mathrm{m}^{2}\right)$.

(c) Largest Patch Index (LPI): the area of the largest patch in each class (in hectares).

$$
L P I=\frac{\max _{j=1}^{n}\left(a_{i j}\right)}{A}(100)
$$

Where $\mathrm{a}_{\mathrm{ij}}=$ area $\left(\mathrm{m}^{2}\right)$ of patch $\mathrm{ij}$.

$\mathrm{A}=$ total landscape area $\left(\mathrm{m}^{2}\right)$.

(d) Class percentage of landscape (PLAND). It equals the percentage of the landscape comprised of the corresponding class type

$$
\% L A N D=(C A / T L A) * 100 .
$$

(e) Patch cohesion index $(\mathrm{COH})$ equals 1 minus the sum of patch perimeter (in terms of number of cell surfaces) divided by the sum of patch perimeter times the square root of patch area (in terms of number of cells) for patches of the corresponding patch type, divided by 1 minus 1 over the square root of the total number of cells in the landscape, multiplied by 100 to convert to a percentage.

$$
\text { COHESION }=\left[1-\frac{\sum_{j=1}^{m} p_{i j}}{\sum_{j=1}^{m} p_{i j} \sqrt{a_{i j}}}\right]\left[1-\frac{1}{\sqrt{A}}\right]^{-1} \cdot(
$$

Where $\mathrm{p}_{\mathrm{ij}}=$ perimeter of patch $\mathrm{ij}$ in terms of number of cell surfaces.

$a_{i j}=$ area of patch $i j$ in terms of number of cells.

$\mathrm{A}=$ total number of cells in the landscape.

\section{Results and analysis}

\subsection{Land use/ cover change}

The areal change of Wuhan (between 1987 and 2005) was calculated from land use classes in the classified satellite images (Figs 2-4). For each land use category, change was calculated as the ratio of the difference in area between a succeeding year, $k+1$ and the initial year, $k$.

\subsubsection{Land use change: 1987 to 1994}

The results show that of the four land use classes, only forest class decreased between 1987 and 1994 . This is understandable, as urban expansion and agriculture/farming occur at the expense of forest cover. There was nearly 30 percent (29.7 percent) increase in urban class from 4.8 percent in 1987 to 6.2 percent in 1994 . This 
could best be explained by the social and economic reforms initiated in 1978. The main feature of the reform was the move from a centrally-planned economy to one of limited market economy. The possibility for indigenes to own their businesses was guaranteed during this period. More importantly, economic reforms made direct foreign investment possible. Many foreign firms began streaming into Wuhan as early as the early 1980s. Its strategic position and recognition as the cradle of economic power in central China made it to be granted preferential policies in 1980 as a port for foreign trade by the State Council. This was followed by its designation in 1984 as the experimental city for economic reform. Land reforms in mid 1980s also made it possible for individuals and private institutions to lease land from the State (as all urban land under the reform belonged to the State). This accelerated massive private and cooperate urban construction of residential, estate as well as business houses. The positive imprint on the city's economy is seen in the nearly four fold dramatic growth of its GDP (Table 3) between 1987 and 1994. Such a growth in the economy, and hence infrastructure, served as pull factor for population from rural areas and other parts of the country (Guo-hui, 1990; Shen, 2002; Yin et al, 2005). Even though China had limited restrictions on the movement of migrant workers, this did not deter the growth of Wuhan's population during this period from 6.29 million in 1987 to 7 million in 1994. Much of this increase could be attributed to population drift from rural areas into the city. What could have been the motivation was the increase in annual net income in the main urban administrative areas, as against rural areas as given by correlation result (Table 3).Many people abandoned the countryside to seek employment in the city, where, annual savings were healthy. Growth in population (Kundu, 2001) had been identified as one factor that contributed greatly to the growth of Wuhan's economy and its areal expansion. This is because migrant workers (from rural areas) provided cheap labour in the construction industry, and hence spur the overall economy of the city.

The result for gross agricultural output observed in the agricultural sector (Table 3) explains the huge areal extent of land put under cultivation, which increased from 44.7 percent in 1987 to over half (55.3 percent) of the entire land area of Wuhan in 1994. This increase in agricultural cultivation supports the claim that population increase necessitates food production, a key requirement for man's survival. This further supports the view that economic growth and population increase (Table 3) accelerated land use in Wuhan during this period. The increases in urban and agricultural land saw a 20.5 percent disappearance of forest cover during this period.

\subsubsection{Land use change: 1994 to 2005}

The increase in urban class observed between 1987 and 1994 continued during this period. It increased more than 100 percent from 6.2 percent to 13.0 percent. This could be attributed to the major economic and social policies and decisions that were taken during this period. For example, it again bagged favor from the central government for preferential policies in 2000 to become the flagship to spur economic development to the western interior under the 'Great Western Development' campaign programme. The Wuhan Master Plan of 1996-2020 prepared between 1993 and 1996 also gained State approval in 1999. Before approval though, such development as the completion of the second highway bridge (upper reaches) over the Yangtze River took place in 1994. Together with the first bridge, this helped to create the first ring road of Wuhan. The ring remarkably improved overall accessibility by linking the three towns. The approval saw it receive huge funds for key infrastructural projects such as highways and city interchanges and the subway system. This period was generally characterized by mainly two key issues: changes in urban land use otherwise referred to as urban redevelopment and transformation of existing structures in the city, and economic restructuring of the primary, secondary and tertiary industries.

One of the great achievements of this was the establishment of three (3) state-level development areas: the Wuhan Economic and technology Development Zone, the Wujiashan Taiwan Businessman Investment Zone, and the Wuhan East lake High-Tech Development Zone. These comprised the major industrial bases that were reformed and/or developed out of the previous heavy manufacturing structure.

The decision to allow foreign investment saw an increase in foreign direct investment, from 913.43 million Yuan to 1,770.01 million Yuan, within the 11-year period. This surely promoted infrastructural development and economic growth. This also increased the GDP, by nearly five times (Table 3). The population too swelled by more than a million, because influx from rural areas and other provinces was encouraged by the relaxation of movement of migrant workers to the city (Lopez et al, 2006). Per capital annual urban savings increased nearly three times during this period.

An interesting scenario is observed when one compares percentage increase in urban land use to that of forest. As generally expected, urban land should increase at the expense of forest land. However, figures show that percent change in forest land during the 11-year period between 1994 and 2005 is minimal compared to that in the 7-year period between 1987 and 1994. This could be attributed to the policy on the protection of forests in 
1985, and that of agricultural land that was enacted in 1994. Not only was afforestation encouraged, but forest conversion to other land uses was minimized. This was translated in the amount of land put under agricultural use. Percent increase in agricultural land during this 11-year period was smaller compared to that during the 7-year period. However, such a reduction in agricultural land use did not affect or reduce agricultural output, as seen in the output figures (Table 4). Increase in mechanization and hybrid technology could have done the trick, hence the observed increase in production.

The decrease in water could firstly be attributed to the division of some water bodies into smaller ones. And as Deng, (2005) pointed out, ecosystem of small lakes and marsh wetlands is fragile and tends to decline either naturally or artificially. Secondly, some water bodies found in urban settings were reclaimed to have urban structures. This practice may have reduced the burden on forested areas.

\subsection{Relationship between urban expansion and socioeconomic variables}

The relationship between urban expansion and socioeconomic variables was computed using Pearson's moment correlation coefficient, $r$. Table 3 presents results for Pearson product moment correlation coefficient, $r$ between urban class and socioeconomic variables. The results showed that population, GDP, per capita GDP, gross agricultural production, per capita annual net rural income and per capita annual net urban income, were all strongly correlated with urban expansion in the order: GDP > per capita GDP > per capita annual net urban income $>$ per capita annual net rural income population $>$ total population $>$ gross agricultural production $>$ FDI. These results indeed confirm a number of literatures on drivers of urban growth (as also explained in 3.1 above). Gross domestic product is an indicator of economic growth and which in itself encourages more land use. The healthy income in urban areas, but poor income in rural areas, provoked migration into the city, as indicated by the results. This was also shown by result for population. Increased migration from the rural areas, as a result of the relaxation of migration rules from rural to urban areas, gave rise to more residential structures to be built on Wuhan's fringes. Migrant workers were also identified as the unskilled workers in the construction industry.

\subsection{Ecological implications of land use change}

Landscape metrics have been helpful tools in understanding the ecological implications of human-activities on the landscape. In this study, the effects of land use change on the Wuhan landscape discussed above have been quantified using various metrics. Tables 4 and 5 present metrics calculated using Fragstats 3.3 at both the landscape and class levels.

\subsubsection{Changes in landscape patterns}

Table 4 shows that NP, PD, LPI and CONT increased between 1987 and 1994. But while NP and PD decreased in the next period, 1994-2005, LPI and CONT continued the increase during that period. Increase in NP between 1987 and 1994 indicates that fragmentation strengthened in Wuhan during this period, giving rise to a complex assemblage of isolated and diverse landscape patches and ecological processes. Numerous studies have shown disparity in biotic and abiotic factors within adjoining patch (Harper et al. 2005; Ries et al. 2004; Sisk et al. 2002). Associated with this are increased edge habitats and their effects (Couvillion, 2005), and greater loss of connectivity. This is because edges have the tendency to change the biological and physical conditions around patch boundaries and within adjacent patches (Ries et al. 2004; Harper et al. 2005). Fragmentation of a landscape itself is of greater concern, not least because it creates a natural imbalance in terms of size, shape and distribution of mosaic of patches found within the human dominant landscapes (Riiters et al, 2000). The significant of this is that it influences the dynamics of species and material in the landscape (Forman, 1995), giving various ecosystems their unique structure and function. Characteristic of these ecosystems include distinct requirements nutrients, temperature, of climate, physiographic, soil, water, hydrology, air and potential natural communities.

The 12.81 percent increase in NP (335962 to 379009) from 1987 to 1994 could be attributed to increased human activities (that characterized this period), in response to the economic and social reforms made across the entire country. Much of such activities could be credited to increase in impervious layers across the landscape. This increase in impervious surfaces could be attributed to increase in population, and economic growth, which is reflected in its gross domestic product. These have been found to have positive relationship with increase in NP and hence increased landscape mosaics (Xu et al, 2010).

The observed decrease in NP during 1994-2005 does not indicate a reduction in human activities on the landscape such as urban expansion or agricultural activities, but could rather be the result of similar isolated patches joined to one another. Such aggregation of similar patches takes place when corridors are eliminated between similar patches, their connectivity increased, and their edges joined together. In the case of human habited areas for example, isolated settlements and villages may have joined to each other. The city itself assumed a more compact or organized expansion, rather than characterized by dispersed or isolated patches. 
Smaller parcels of agricultural fields may have aggregated together by either, clearing and putting under cultivation more forest patches existing between the plots, or such patches replaced by other land use classes such as through afforestation or urban expansion. This assertion could be attributed to the land laws, especially those on construction land and urban restructuring, and agricultural land, and forest law that came into effect during this period and which saw a more or less organized and planned land use practices in both rural and urban areas, hence the 26 percent drop in NP between 1994 and 2005.

In the case of Patch Density, the 1987-1994 period saw an increase in total area of patches across the landscape as a result of increase in NP. This decreased with the NP between 1994 and 2005, as similar patches aggregated together. Such a conclusion is also supported by results for Contagion Index (CONT) and Fractal Dimension Index (FDI). Contagion Index, which shows spatial aggregation of patches, increased throughout the study period. Such an increase, away from zero, indicates more aggregation (McGarigal and Marks, 1994). There was more aggregation of patches in Wuhan's landscape during the 11-year period (1994 to 2005), than the 7-year period (1987 to 1994), which were $12.0 \%$ (45.8 to 51.3) and 6.2\% (45.8 to 43.1) respectively. Such aggregation takes place when similar isolated patches joined their edges to one another. This means existing corridors between similar patches were eliminated to enable their aggregation.

Unlike Contagion, a move towards zero shown by the decrease in Fractal Dimension Index from 1987 to 1994 and then 1994 to 2005, was an indication of regularity in the landscape. The fragmentation of Wuhan generally became weakened from 1987 to 2005 . Though it had many patch types (in this case land use classes), the size of the different patches became larger in relation to the total number of patches in the landscape. This reduced the number of patches in the landscape, by the aggregation of similar patches together. Such aggregation reduces the number of varied ecosystem assemblages and hence diverse ecological processes in the landscape.

Results for Largest Patch Index (LPI) clearly go with this assertion. Between 1987 and 1994, LPI increased by 46.11 percent (10.2 to 14.9), and gigantically increased by nearly 120 percent from 1994 to 2005 (14.9 to 35.7). This clearly shows that some land use classes dominated the landscape throughout these periods. For example, whilst, urban structures might have expanded, more agricultural fields were also put under cultivation, especially between 1994 and 2005(Table 4). Impervious layers, including buildings, tarmac roads, and rails expanded and increased not only in the urban setting, but rural communities. What is seen in the urban and rural areas today is a well organized and planned city, with massive infrastructural development. Agricultural lands and water bodies have also been managed, such that there are larger agricultural and water bodies on its landscape, instead of smaller patches dotted about. Dominant landscape patches means that the biotic and abiotic factors existing within them influence the general biotic and abiotic conditions in the landscape entirely. For example, whilst forest lands have dwindled, and that of urban areas increased, factors such as temperature, humidity, precipitation, moisture, soil condition, and exchange of material and energy are all altered greatly. This also gives rise to micro climate.

Shannon's Diversity and Simpson's Diversity Indices, which explain fragmentation, show similar trends, with both decreasing throughout the period under study. Shannon's Diversity Index decreased by 3.64 percent $(1.1770$ to 1.1341) between 1987 and 1994, and a further 5.41 percent (1.1341 to 0727) between 1994 and 2005. Similarly, Simpson's Diversity Index, decreased from 6.41 percent (0.6584 to 0.6162), between 1987 and 1994 , to 8.71 percent ( 0.6162 to 0.5625$)$, between 1994 and 2005 . With both of these indices going towards zero, the landscape showed more of aggregation than fragmentation between 1987 and 2005. Fragmentation and hence ecological processes in the landscape thus receded throughout the study period.

\subsubsection{General trend at the class level}

Table 5 gives results of metrics at the class level in Wuhan between 1987 and 2005. It shows that the percentage of urban and agricultural land use classes increased throughout the study period in the entire landscape. Whilst percentage of water increased between 1987 and 1994 but decreased from 1994 to 2005, that of forest decreased throughout. It further shows that urban and agricultural classes occupied nearly half $(49.72 \%)$ of the landscape in 1987, increased to over 60 percent (61.50\%) in 1994, and to three-quarters $(75.47 \%)$ in 2005

The original natural status of the landscape was thus altered and/ or transformed significantly, possibly giving rise to new biotic life forms and abiotic factors, and relationships. For example, the intensity of fragmentation caused by agricultural class indicates replacement of a greater number of fauna life forms with a few selected ones like crops. The increased in urban land class, by nearly 300 percent from 1987(4.80\%) to 2005(13.00\%), indicates a greater loss of the natural ecosystem to infrastructural development. And both of these classes (urban and agriculture) oftentimes increase at the expense of forest class, little wonder it decreased by more than 200 percent, from 32.61 percent in 1987 to 13.44 percent in 2005. This shows that Wuhan's landscape underwent 
massive loss of its natural habitat within an 18-year period. Such fragmentation processes, and possible loss of habitats, have greater effect on biodiversity conservation in landscapes undergoing anthropogenic land use changes. Not only are flora life forms destroyed, but animals are threatened with extinction, as they migrate to other places where conditions for their existence may be different from their previous natural habitats.

This concern and conclusion is also supported by results for LPI, which increased throughout the study period for both urban and agricultural land use classes, but decreased for those of forest and water. In the case of urban land use class, one could infer that elimination of other land use classes such as agricultural, and reduction of forest and water may have taken place between urban patches. This gave urban patches greater connectivity, and hence aggregating and consolidating, with more regular pattern observed in the entire landscape. Decrease index observed in forest class is quite expected, as they always dwindle when urban and agricultural classes increase. Decrease in forest and increase in urban areas generally result in increased temperature, heat, and sunshine.

The increase in agriculture patch index could be pictured as smaller agricultural fields aggregating together outside of urban areas into the more open countryside. Agricultural practice therefore became more organized and plots regular.

This assertion is observed in its NP and PD. They decreased throughout the study period. This were not however the case in the other land use classes, where alternate increase and decrease were observed from 1987 to 1994 , and 1994 to 2005 respectively. With reference to agricultural class, one could infer that either some agricultural fields were eliminated and/or replaced with other land use classes, or smaller parcels of agricultural fields were aggregated together, hence reducing the number of patches. Fragmentation of the landscape through agriculture could be said to have weakened during the period under study. This cannot be said of the other classes. Whilst their results show that fragmentation intensified during the 1987-1994, leading to more spatial variability and complex landscape, there was a turn around between 1994 and 2005, when fragmentation appeared to have receded. Heterogeneity and irregularity in the landscape was thus reduced during the 1994-2005 period. Forest patches reduced, which, as expected, might have been due to the total obliteration of some forest patches to make way for more urban land use. Aggregation of isolated urban patches might have taken place.

Results for cohesion, which increased throughout the study period for urban class and agricultural class, but decreased for the other two classes, buttress this assertion. Greater connectivity was observed in urban, and agricultural patches as their edges joined together, and corridors between similar patches eliminated. Edge effects, and smaller ecosystems, that oftentimes produce variety of ecosystem structure and function, may have been reduced considerably. This scenario explains the success of the urban land use policy adopted in the mid-1990s, which saw the elimination or shifting out of all agricultural fields from among urban areas, towards the fringes. Agricultural fields therefore expanded from the urban fringes into more rural areas. At the same time, forested areas dwindled to a point that policy on afforestation and urban green were adopted in the late 1990s to save the total extinction of forest class in Wuhan. And within the city areas, land reclamation, involving little water bodies took place. This is shown by decrease in LPI in the water class.

\section{Conclusion}

This study analyzed land use, and its ecological implications in Wuhan between 1987 and 2005. Results showed that urban land use increased throughout the study period. Wuhan's strategic position in central China, and special privileges accorded by the central government accelerated economic growth that led to loss of its arable land. This too resulted in changes in its landscape structure and composition, as evidenced by variability (between the time periods) in the metrics. This study therefore proved the capability of remote sensing and GIS to quantify changes in natural resource over time. Fragstats too was able to describe the ecological effects of such changes. What is needed now is to have an inventory of fauna and flora life forms in a bid to establish the numerical effects of land use land cover changes in the landscape. Variations in climatic and edaphic factors are also a gray area for research.

\section{References}

Allen, T. F. H and Hoekstra, T. W. (1992). Towards a Unified Ecology. New York: Columbia University Press

Anderson, et al. (1976). A Land Use and Land Cover Classification System for Use with Remote Sensor Data. Geological Survey Professional Paper No. 964, U.S. Government Printing Office, Washington, D.C. p. 28.

Aranzabal Itziar, D., Schmitz, Marie F., Aguilera, Pedro and Pineda, Francisco, D. (2008). Modelling of landscape changes derived from the dynamics of socio-ecological systems. A case of study in a semiarid Mediterranean landscape. Ecological Indicators, 8, 672-685. doi:10.1016/j.ecolind.2007.11.003, http://dx.doi.org/10.1016/j.ecolind.2007.11.003 
Benjaminsen, T. A. (2001). The population-agriculture-environment nexus in the Malian cotton zone. Global Environ Change, 11, 283-295. doi:10.1016/S0959-3780(01)00006-1, http://dx.doi.org/10.1016/S0959-3780(01)00006-1

Braimoh Ademola, K. and Onishi, T. (2007). Spatial determinants of urban land use change in Lagos, Nigeria. Land Use Policy, 24, 502-515. doi:10.1016/j.landusepol.2006.09.001, http://dx.doi.org/10.1016/j.landusepol.2006.09.001

Briassoulis Helen. (1999). Analysis of Land use change: Theoretical and Modeling Approaches. In: The Web Book of Regional Science.(ed.) Loveridge, S.West Virginia, Regional Research Institute, West Virginia University. [Online] Available: http://www.rri.wvu.edu/WebBook/Briassoulis/contents.htm.

Buchecker, M., Hunziker, M., Kiensat, F. (2003).Participatory landscape development: overcoming cosical barriers to public improvement. Landscape Urban Planning, 64, 29-46. doi:10.1016/S0169-2046(02)00199-8, http://dx.doi.org/10.1016/S0169-2046(02)00199-8

Bürgi, M., Turner, M. G. (2002). Factors and processes shaping land cover and land cover changes along the Wisconsin River. Ecosystems, 5, 184-201. doi:10.1007/s10021-001-0064-6, http://dx.doi.org/10.1007/s10021-001-0064-6

Cheng, J. (2003). Modelling spatial and temporal urban growth. Doctoral Dissertation submitted to Utrecht University, Faculty of Geographical Sciences, Utrecht The Netherlands.

Cheng, J. Q. and Masser, I. (2003). Urban growth pattern modeling: a case study of Wuhan city, PR China. Landscape urban Planning, 62, 199-217. doi:10.1016/S0169-2046(02)00150-0, http://dx.doi.org/10.1016/S0169-2046(02)00150-0

Chibamba Douty. (2009). An Assessment of Land Use and Land Cover Changes in Wuhan City during 1987-2006: Integrated Geospatial-Socioeconomic Data Approach. A Dissertation Submitted to China University of Geosciences for the Degree of Doctor of Philosophy.

Costanza, R., d'Arge, R., de Groot, R., Farber, S., Grasso, M., Hannon, B. (1997). The value of the world's ecosystem services and natural capital. Nature, 387(15), 253-260. doi:10.1038/387253a0, http://dx.doi.org/10.1038/387253a0

Couvillion Randall Brady. (2005). Spatial Heterogeneity In: Forested Landscapes: An Examination of Forest Fragmentation and Suburban Sprawl In The Florida Parishes Of Louisiana. Master of Science Thesis submitted to The Department of Geography and Anthropology, Graduate Faculty of the Louisiana State University and Agricultural and Mechanical College.

Cushman Samuel, A., McGarigal, Kelvin and Neel, Maile, C. (2008). Parsimony in landscape metrics: strength, universality, and consistency. Ecological Indicators, 8, 691-703. doi:10.1016/j.ecolind.2007.12.002, http://dx.doi.org/10.1016/j.ecolind.2007.12.002

Deng, H. B. (2005). Research on Jianghan lake groups and evolution and lake area regional sustainable development. Beijing: Economic Science Press (in Chinese).In: Kai Xu, Chunfang Kong, Gang Liu, Chong long Wu, Hongbin Deng, Yi Zhang and Qianlai Zhuang. 2010. Changes of urban wetlands in Wuhan, China, from 1987 to 2005. Progress in Physical Geography, 34, 207.

Environmental Protection Agency. (1999). Land Cover Trends: Rates, Causes, and Consequences of Late-Twentieth Century U.S. Land Cover Change. EPA/600/R-99/105 June. United States Env. Protection Agency, 'Washington DC 20460.

Forman, R. T. T. (1995). Land Mosaics: the ecology of landscapes and regions. Cambridge: Cambridge University Press

Foster, D., Swanson, F., Aber, J., Burke, I., Brokaw, N., Tilman, D., Knapp, A. (2003). The importance of land-use legacies to ecology and conservation. Biosciences, 53(1), 77-88. doi:10.1641/0006-3568(2003)053[0077:TIOLUL]2.0.CO;2, http://dx.doi.org/10.1641/0006-3568(2003)053[0077:TIOLUL]2.0.CO;2

Gan Guo-hui. (1990). Perspective of urban land use in Beijing. GeoJournal, 20(4), 359-364.Kluwer Academic Publishers.

Glicken, J. (2000). Getting stakeholder participation 'right': a discussion of participatory processes and possible pitfalls. Environmental Science Policy, 3, 305-310. doi:10.1016/S1462-9011(00)00105-2, http://dx.doi.org/10.1016/S1462-9011(00)00105-2 
Guo, H., Liu, L., Huang, G., Fuller, G., Zou, R., \& Yin, Y (2001). A system dynamics approach for regional environmental planning and management: A study for the Lake Erhai Basin. Journal of Environmental Management, 61, 93-111. doi:10.1006/jema.2000.0400, http://dx.doi.org/10.1006/jema.2000.0400

Gustafson, E. J., (1998). Quantifying landscape spatial pattern: what is the state of the art? Ecosystems, 1, 143-156. doi:10.1007/s100219900011, http://dx.doi.org/10.1007/s100219900011

Haines-Young, R., \& Chopping, M. (1996) Quantifying landscape structure: a review of landscape indices and their application to forested landscapes. Progress in Physical Geography, 20, 418-445. doi:10.1177/030913339602000403, http://dx.doi.org/10.1177/030913339602000403

Harper, K. A., Macdonald, S. E., Burton, P. J., Chen, J.,Q., Brosofske, K. D., Saunders, S. C. et al. (2005). Edge influence on forest structure and composition in fragmented landscapes. Conservation Biology, 19, 768-782. doi:10.1111/j.1523-1739.2005.00045.x, http://dx.doi.org/10.1111/j.1523-1739.2005.00045.x

International Geosphere-Biosphere Program Committee on Global Change. (1988). Toward an understanding of Global Change. National Academy Press, Washington, DC

Jat Mahesh Kumar., Garg, P. K. and Khare, Deepak. (2008). Monitoring and modeling of urban sprawl using remote sensing and GIS techniques. International Journal of Applied Earth Observation and Geoinformation, 10, 26-43. doi:10.1016/j.jag.2007.04.002 http://dx.doi.org/10.1016/j.jag.2007.04.002

Jensen J. R. (2007). Introductory digital image processing: A remote sensing perspective, 3rd edition. Beijing: Science Press and Pearson Education Asia Ltd.

Kai Xu, Chunfang Kong, Gang Liu, Chonglong Wu, Hongbin Deng, Yi Zhang and Qianlai Zhuang (2010). Changes of urban wetlands in Wuhan, China, from 1987 to 2005. Progress in Physical Geography, 34, 207. doi:10.1177/0309133309360626, http://dx.doi.org/10.1177/0309133309360626

Kong Fanhua and Nakagoshi, Nobukazu.(2006). Spatial-temporal gradient analysis of urban green spaces in Jinan, China. Landscape and urban Planning, 78, 147-164.http://dx.doi.org/10.1016/j.landurbplan.2005.07.006

Kundu Amitabh. (2001). Urban Development, Infrastructure Financing and Emerging System of Governance in India: A Perspective. Discussion Paper, 4(48), 15 Management of Social Transformations

Lacitignola D., Petrosillo, I., Cataldi, M., and Zurlini, G (2007). Modelling socio-ecological tourism-based systems for sustainability. Ecological Modelling, 206, 191-204. doi:10.1016/j.ecolmodel.2007.03.034, http://dx.doi.org/10.1016/j.ecolmodel.2007.03.034

Lambin E. F., Rounsevell, M. D. A and Geist, H. J. (2000). Are agricultural land-use models able to predict changes in land-use intensity? Agriculture, Ecosystems and Environment, 82, 321-331. doi:10.1016/S0167-8809(00)00235-8, http://dx.doi.org/10.1016/S0167-8809(00)00235-8

Lambin Eric, F., Turner, B. L., Geist, Helmut J., Agbola, Samuel B., Angelsen, Arild, Bruce, John W. et al. (2001). The causes of land-use and land-cover change: moving beyond the myths. Global Environmental Change, 11(4), 261-169. doi:10.1016/S0959-3780(01)00007-3, http://dx.doi.org/10.1016/S0959-3780(01)00007-3

Lambin, E. F., Baulies, X., Bockstael, N., Fischer, G., Krug, T., Leemans, R., Morgan, E. F., Rindfuss, R. R., Sato, Y., Skole, D., Turner, II, B. L., and Vogel, C.(1999). Land-use and land-cover change (LUCC) implementation strategy. IGBP Report 48 and IHDP Report 10, Stockholm, Bonn

Leitao, A. B. and Ahern, Jack. (2002). Applying landscape ecological concepts and metrics in sustainable landscape planning. Landscape and Urban Planning. 59, 65-93. doi:10.1016/S0169-2046(02)00005-1, http://dx.doi.org/10.1016/S0169-2046(02)00005-1

Liu, J. and Ashton, P. S. (1998). FORMOSAIC: an individual-based spatially explicit model for simulating forest dynamics in landscape mosaics. Ecol. Modell, 106, 177-200. doi:10.1016/S0304-3800(97)00191-9, http://dx.doi.org/10.1016/S0304-3800(97)00191-9

Lopez Erna, Bocco, G., Mendoza, M., Velazquez, A. and Aguirre, J. R. (2006). Peasant emigration and land-use change at the watershed level: A GIS-based approach in Central Mexico. Agricultural Systems, 90, 62-78. doi:10.1016/j.agsy.2005.11.001, http://dx.doi.org/10.1016/j.agsy.2005.11.001

Mather, A. S. (1999). Land use and cover change. Land use policy, 16, 143.

Matthews, R. (2006). The people and landscape model (PALM): towards full integration of human decision-making and biophysical simulation models. Ecological Modelling, 194, 329-343. doi:10.1016/j.ecolmodel.2005.10.032, http://dx.doi.org/10.1016/j.ecolmodel.2005.10.032 
McDonnell, M. J and Pickett, S. T. A. (1988). Connectivity and the Theory of Landscape ecology.

McGarigal Kevin, Marks, Barbara, J. (1995). Fragstats: Spatial Pattern Analysis Program for Quantifying Landscape structure. USDA Forest service General Technical Report PNW-GTR-351.

McGarigal, K., Marks, B. J. (1994). Fragstats-Spatial Pattern Analysis Program for Quantifying Landscape structure. Forest science Department, Oregon State University, Corvallis

McGarigal, K., S. A. Cushman, M. C. Neel, and E. Ene. (2002). Fragstats: Spatial Pattern Analysis Program for Categorical maps. Computer software program produced by the authors at the University of Massachusetts, Amherst. [Online] Available: http://www.umass.edu/landeco/research/fragstats.html

Medley, K. E., Okey, B. W., Barrett, G. W., Lucas, M. F., and Renwick, W. H. (1995). Landscape change with agricultural intensification in a rural watershed, southwestern Ohio, U.S.A. Landscape Ecology, 10, 161-176. doi:10.1007/BF00133029, http://dx.doi.org/10.1007/BF00133029

Milesi Cristina, Hashimoto, Hirofumi., Running, Steven, W. and Nemani, Ramakrishna, R. (2005). Climate variability, vegetation productivity and people at risk. Global and Planetary Change, 47, 221-231. doi:10.1016/j.gloplacha.2004.10.020, http://dx.doi.org/10.1016/j.gloplacha.2004.10.020

Milesi, C. D., Elvidge, R. R., Nemani, S. W. (2003). Assessing the impact of urban land development on net primary productivity in the Southeastern United States. Remote Sensing of Environment, 86, 401-410. doi:10.1016/S0034-4257(03)00081-6, http://dx.doi.org/10.1016/S0034-4257(03)00081-6

Nagashima Keiko et al. (2002). Regional landscape change as a consequence of plantation forestry expansion: an example in the Nelson region, New Zealand. Forestry Ecology and Management, 163, 245-261. doi:10.1016/S0378-1127(01)00583-7, http://dx.doi.org/10.1016/S0378-1127(01)00583-7

Palmer James, F. (2004). Using spatial metrics to predict scenic perception in a changing landscape. Landscape and urban Planning, 69, 201-218. doi:10.1016/j.landurbplan.2003.08.010, http://dx.doi.org/10.1016/j.landurbplan.2003.08.010

Pielou, E. C. (1977). Mathematical ecology. New York: John Wiley and Sons.

Ries L., Fletcher, R. J., Battin, J. \& Sisk, T. D. (2004). Ecological responses to habitat edges: mechanisms, models, and variability explained. Annual Review. Ecological. Systems, 35, 491-522. doi:10.1146/annurev.ecolsys.35.112202.130148, http://dx.doi.org/10.1146/annurev.ecolsys.35.112202.130148

Riitters, K., Wickham, J., O'Neill, R., Jones, B. \& Smith, E. (2000). Global-scale patterns of forest fragmentation. Conservation Ecology, 4(2), 3 [Online] Available: http://www.consecol.org/vol4/iss2/art31

Sepp Kalev. (2007). Studying landscape change: Indicators, assessment and applications. Landscape and Urban Planning, 125-126.

Shen Jianfa. (2002). Urban and Regional development in post-reform China: the case of Zhujiang delta. Progress in Planning, 57, 91-140. doi:10.1016/S0305-9006(01)00022-8, http://dx.doi.org/10.1016/S0305-9006(01)00022-8

Sisk T. D., Noon, B. R. \& Hampton, H. M. (2002). Estimating the effective area of habitat patches in heterogeneous landscapes. In: Predicting Species Occurrences: Issues of Accuracy and Scale (eds Scott, M., Heglund, P., Morrison, M. L., Haufler, J. B., Raphael, M. G., Wall, W. A. \& Samson, F. B.). Island Press, Washington, DC, pp. 713-725.

Sonis, M., Shohany, M., and Goldshlager, N. Landscape Changes in the Israeli Carmel Area: application of matrix land-use analysis In: Koomen, E., et al. (2007). Modelling Land-Use Change 61-82 @2007 Springer State Statistical Bureau, various Years. China Statistics Yearbook. Praeger, New York.

Tan Minghong., Li, Xiubin. Xie, Hui and Lu, Changhe. (2005). Urban land expansion and arable land loss in China-a case study of Beijing-Tianjin-Hebei region. Land Use Planning, 22, 187-196. doi:10.1016/j.landusepol.2004.03.003, http://dx.doi.org/10.1016/j.landusepol.2004.03.003

Trimble, S. W. and Crosson, P. (2000). Land use: U.S. soil erosion rates. Myth and reality. Science, 289, 248-250. doi:10.1126/science.289.5477.248, http://dx.doi.org/10.1126/science.289.5477.248

Turner, M. D. (2003) .Environmental science and social causation in the analysis of Sahelian pastorarism.

Turner, M. G. (2005).Landscape ecology in North America: past, present and future. Ecology, 86, 1967-1974. doi:10.1890/04-0890, http://dx.doi.org/10.1890/04-0890 
Van der Venn, A. and Otter, H. S. (2001). Land use changes in regional economic theory. Environmental Modeling and Assessment, 6, 145-150. doi:10.1023/A:1011535221344, http://dx.doi.org/10.1023/A:1011535221344

Veldkamp, A., Verburg, P. H. (2004). Modelling land use change and environmental impact. Journal of Environmental Management, $72 \quad(1-2), \quad 1-3 . \quad$ doi:10.1016/j.jenvman.2004.04.004, http://dx.doi.org/10.1016/j.jenvman.2004.04.004

Vitousek, P. M., Mooney, H. A., Lubchenco, J. and Melilo, J. M. (1997). Human dominated Earth's ecosystems, Science, 277(5325), 494-499. doi:10.1126/science.277.5325.494, http://dx.doi.org/10.1126/science.277.5325.494

Wang Yeqiao and Zhang, Xinsheng (2001). A dynamic modeling approach to simulating socioeconomic effects on landscape changes. Ecological Modelling, 140, 141-162. doi:10.1016/S0304-3800(01)00262-9, http://dx.doi.org/10.1016/S0304-3800(01)00262-9

Wiens, J. A. (1989). Spatial scaling in ecology. Functional ecology, 3, 385-397. doi:10.2307/2389612, http://dx.doi.org/10.2307/2389612

Wu Qiong, Li, Hong-qing, Wang, Ru-song, Paulussen, Juergen, He, Yong,Wang, Min, Wang, Bi-hui, and Wang, Zhen. (2006). Monitoring and predicting land use change in Beijing using remote sensing and GIS. Landscape and urban Planning, 78, 322-333. doi:10.1016/j.landurbplan.2005.10.002, http://dx.doi.org/10.1016/j.landurbplan.2005.10.002

$\mathrm{Wu}$, J. and Hobbs, R. (2002). Key issues and research priorities in landscape ecology: an idiosyncratic synthesis. Landscape Ecology, 17, 355-365. doi:10.1023/A:1020561630963, http://dx.doi.org/10.1023/A:1020561630963

Wuhan Statistical Year Book. (2008). Wuhan: Wuhan Press

Wuhan Statistical Year Book. (2009). Wuhan: Wuhan Press

Yeates, M. and Garner, B. (1976). The North American City, New York: Harper and Row Pub.

Yeh Gar-On and Li, Xia. (2002). Urban Simulation using Neural Networks and Cellular Automata for Land Use Planning. Symposium on Geospatial Theory, Processing and Applications, Ottawa 2002

Yin Zhi-Yong et al. (2005). Changes in urban built-up surface and population distribution patterns during 1986-1999: A case study of Cairo, Egypt. Computers, Environment and Urban systems, 29, 595-616. doi:10.1016/j.compenvurbsys.2005.01.008, http://dx.doi.org/10.1016/j.compenvurbsys.2005.01.008

Yingui Xiao. (2002). Spatial-Temporal land use pattern and Master Planning in Wuhan, China. Maters Thesis submitted to International Institute of Geo-information science and earth Observation. Enschede, The Netherlands

Yuan Fei, Sawaya, Kali, E., Loeffelholz and Bauer, Marvin, E. (2005). Land cover classification and change analysis of the Twin Cities (Minnesota) Metropolitan Area by multitemporal Landsat remote sensing. Remote Sensing of Environment, 98, 317-32.

Table 1. Satellite images used

\begin{tabular}{|l|l|l|l|l|}
\hline Date of Acquisition & Data Source & RMSE & Accuracy & kappa \\
\hline $26^{\text {th }}$ Sept 1987 & Landsat $5(\mathrm{TM})$ & 0.17 & 88.1 & 0.87 \\
\hline $29^{\text {th }}$ Sept 1994 & Landsat 5 (TM) & MASTER & 86.55 & 0.85 \\
\hline $6^{\text {th }}$ May, 2005 & Landsat 5 (TM) & 0.18 & 89.06 & 0.86 \\
\hline
\end{tabular}

These three satellite images were used in the classification process to obtain land use classes in Wuhan, between 1987 and 2005. Their accuracy assessment, root mean squared error and kappa index during the supervised classification processes are also presented. 
Table 2. Land use and percent change in land use in Wuhan, 1987 to 2005

\begin{tabular}{|c|c|c|c|c|c|c|c|c|c|c|}
\hline $\begin{array}{l}\text { Land } \\
\text { use } \\
\text { Class }\end{array}$ & $\begin{array}{l}\text { Land use } \\
1987 \\
\text { (ha) }\end{array}$ & $\%$ & $\begin{array}{l}\text { Land } \\
\text { use } \\
1994 \\
\text { (ha) }\end{array}$ & $\%$ & $\begin{array}{l}\text { Change } \\
\text { '87-‘94 } \\
\text { (ha) }\end{array}$ & $\begin{array}{l}\% \\
\text { change } \\
' 87-' 94\end{array}$ & $\begin{array}{l}\text { Land use } \\
2005 \\
\text { (ha) }\end{array}$ & $\%$ & $\begin{array}{l}\text { Change } \\
\text { '94-'05 } \\
\text { (ha) }\end{array}$ & $\begin{array}{l}\% \\
\text { change } \\
\text { '94-'05 }\end{array}$ \\
\hline urban & 18 & 4.8 & 53438. & 6.2 & 12 & 29 & 111 & 13.0 & & 108.9 \\
\hline water & 151780 & 17.7 & 154587 & 18.0 & 280 & 1.9 & & 11.1 & -59400 . & -38.4 \\
\hline agric & 385832 & 44.9 & 474287 & 55.3 & 8845 & 22.9 & 536566 & 62.5 & 62279 & 13.13 \\
\hline forest & 280134 & 32.6 & 177556 & 20.5 & -104378 & -37.3 & 115469 & 13.4 & -60287 & -34.30 \\
\hline
\end{tabular}

Table 3. Socioeconomic variables, and Pearson Product moment correlation coefficient, $r$ with urban growth

\begin{tabular}{|l|c|c|l|l|}
\hline Socioeconomic and demographic variable & 1987 & 1994 & 200 & $\begin{array}{l}\text { Pearson correlation, } \\
r\end{array}$ \\
\hline Total population(10,000) & 629.3 & 700 & 801.36 & 0.9669 \\
GDP(100 Million Yuan) & 124.61 & 485.76 & 2238.23 & 0.9999 \\
Per capital GDP (Yuan/person) & 1995 & 6980 & 26279 & 0.9994 \\
FDI Actually used(10,000 RMB) & 328710 & 91343 & 174001 & -0.8248 \\
Gross Agric Output(10,000RMB) & 216576 & 723819 & 1805957 & 0.9658 \\
Per capital Annual Net Income of rural Pop(Yuan) & 203 & 1432 & 4341 & 0.9915 \\
Per capital Annual Net Income of urban & 1,267 & 3,765 & 10849.72 & 0.9958 \\
population(Yuan) & & & & \\
\hline
\end{tabular}

Source: Wuhan Statistical Year Book, 2009; Correlation coefficient calculated in Microsoft Excel, 2007

Table 4. Landscape level Metrics

\begin{tabular}{|l|l|l|l|l|l|l|l|}
\hline & NP & PD & LPI & CONT & FDI & SHDI & SIDI \\
\hline $\mathbf{1 9 8 7}$ & 335962 & 39.1 & 10.2 & 43.1 & 1.0483 & 1.1770 & 0.6584 \\
\hline $\mathbf{1 9 9 4}$ & 379009 & 44.2 & 14.9 & 45.8 & 1.0461 & 1.1341 & 0.6162 \\
\hline $\mathbf{2 0 0 5}$ & 277783 & 32.3 & 35.7 & 51.3 & 1.0455 & 1.0727 & 0.5625 \\
\hline
\end{tabular}

Table 5. Class Level Metrics

\begin{tabular}{|c|c|c|c|c|c|c|c|c|c|c|c|c|}
\hline & \multicolumn{3}{|c|}{ Urban } & \multicolumn{3}{|c|}{ Water } & \multicolumn{3}{|c|}{ Agric } & \multicolumn{3}{|c|}{ Forest } \\
\hline & 1987 & 1994 & 2005 & 1987 & 1994 & 2005 & 1987 & 1994 & 2005 & 1987 & 1994 & 2005 \\
\hline NP & 88317 & 118293 & 59871 & 39515 & 40803 & 24931 & 88926 & 51904 & 29391 & 119204 & 168009 & 163590 \\
\hline PD & 10.28 & 13.79 & 6.97 & 4.60 & 4.76 & 2.90 & 10.35 & 6.05 & 3.42 & 13.88 & 19.58 & 19.0 \\
\hline LPI & 0.56 & 1.15 & 2.14 & 3.42 & 3.02 & 1.96 & 10.18 & 14.87 & 35.68 & 2.53 & 1.37 & 0.57 \\
\hline $\mathrm{COH}$ & 96.31 & 97.99 & 99.04 & 99.26 & 99.05 & 98.52 & 99.81 & 99.93 & 99.97 & 99.15 & 97.04 & 96.19 \\
\hline$\%$ of LS & 4.80 & 6.23 & 13.00 & 17.67 & 18.02 & 11.08 & 44.92 & 55.27 & 62.47 & 32.61 & 20.48 & 13.44 \\
\hline
\end{tabular}




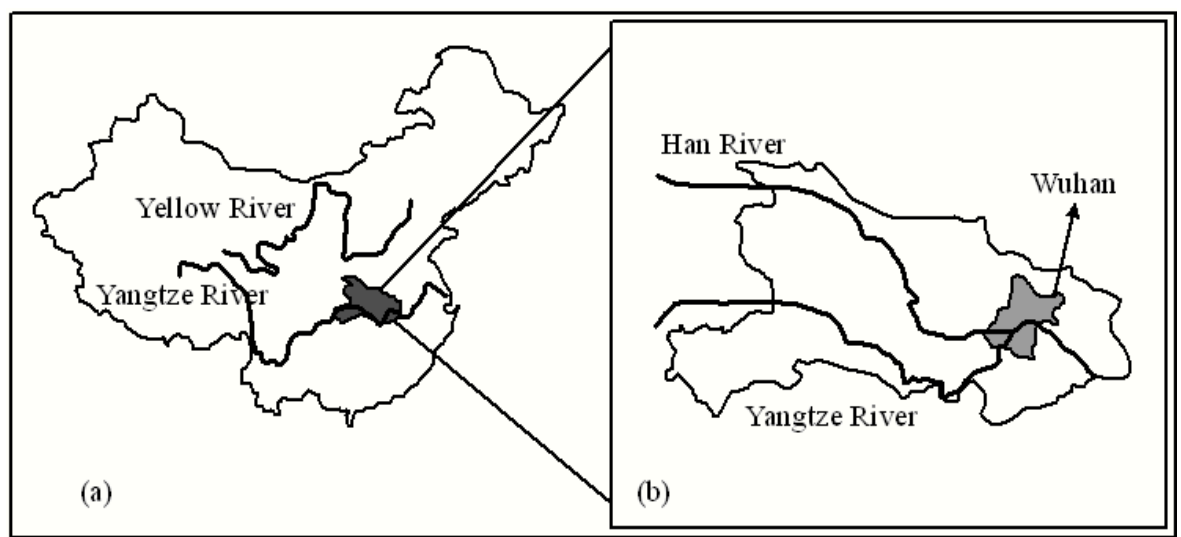

Figure 1. Map of China showing Hubei Province (a), and Hubei Province showing Wuhan (b)

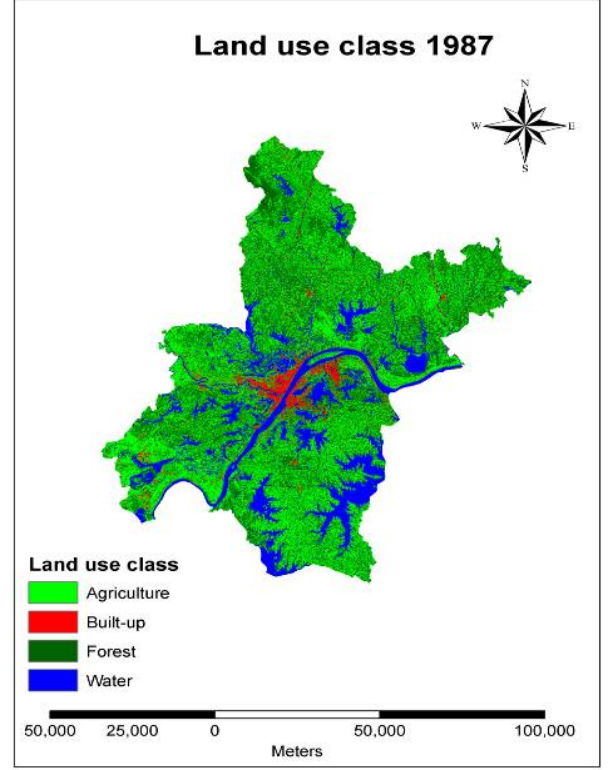

Figure 2. Land use class 1987

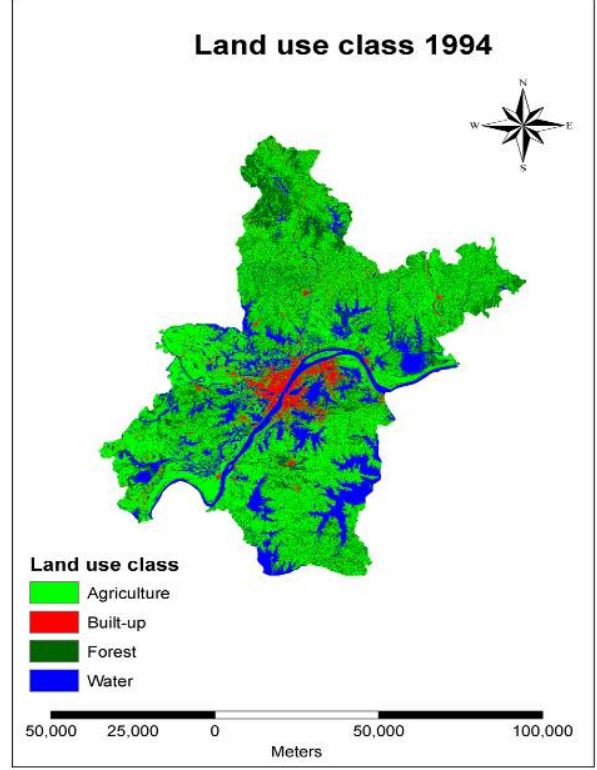

Figure 3. Land use class 1994

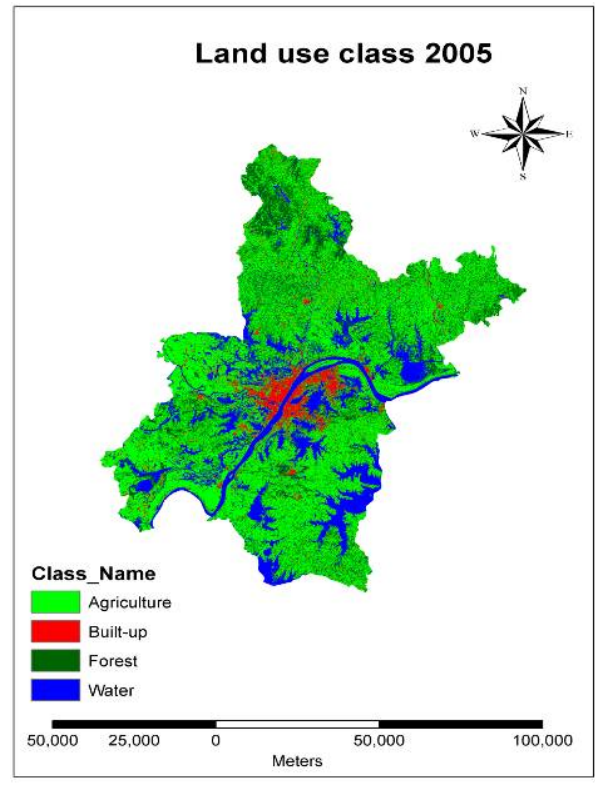

Figure 4. Land use Class 2005 